\title{
PENGEMBANGAN BAHAN AJAR AKUNTANSI UNTUK MENINGKATKAN KOMPETENSI SISWA PADA MATA PELAJARAN PRAKTIK AKUNTANSI MANUAL
}

\section{DEVELOPING ACCOUNTANCY LEARNING MATERIALS TO IMPROVE THE COMPETENCE IN THE MANUAL ACCOUNTANCY PRACTICE SUBJECT}

\author{
Oleh: \\ Riqi Astuti \\ Prodi Pendidikan Akuntansi Universitas Negeri Yogyakarta \\ riqi.astuti@yahoo.com \\ Diana Rahmawati \\ Staf Pengajar Jurusan Pendidikan Akuntansi Universitas Negeri Yogyakarta
}

\begin{abstract}
Abstrak
Tujuan penelitian ini untuk: (1) Mengembangkan Bahan Ajar Akuntansi pada mata pelajaran Praktik Akuntansi Manual; (2) Mengetahui kelayakan Bahan Ajar Akuntansi; (3) Mengetahui penilaian siswa terhadap Bahan Ajar Akuntansi; dan (4) Mengetahui peningkatan Kompetensi Siswa Pada Mata Pelajaran Praktik Akuntansi Manual kelas XI Akuntansi di SMK Negeri 7 Yogyakarta setelah menggunakan Bahan Ajar Akuntansi. Penelitian ini merupakan penelitian pengembangan yang mengacu pada four-D (4D) models. Teknik pengumpulan data dalam penelitian ini yaitu menggunakan angket dan tes. Hasil penelitian ini adalah: (1) Pengembangan Bahan Ajar Akuntansi sesuai dengan model pengembangan four-D models dengan empat tahapan pokok yaitu, define, design, develop, dan disseminate; (2) Kelayakan Bahan Ajar Akuntansi berdasarkan penilaian: ahli materi diperoleh rerata skor 3,93 (layak), ahli media 4,02 (layak), dan praktisi pembelajaran akuntansi 4,03 (layak); (3) Penilaian siswa terhadap Bahan Ajar Akuntansi diperoleh rerata skor 4,33 (sangat layak); (4) Bahan Ajar Akuntansi dapat meningkatkan Kompetensi Siswa Pada Mata Pelajaran Praktik Akuntansi Manual sebesar 59,36\%. Berdasarkan analisis paired sample t-test diperoleh ratarata nilai pretest 4,70 dan posttest 7,49 dengan peningkatan 2,49 , nilai $t_{\text {hitung }}=-46,116$ dengan sig.(p)=0,000 yang menunjukkan adanya perbedaan signifikan antara nilai pretest dan posttest.
\end{abstract}

Kata kunci: Bahan Ajar Akuntansi, Four-D Models, Modul, Praktik Akuntansi Manual

\begin{abstract}
The aims of this research were designed to: (1) develop accountancy learning material; (2) identify the feasibility of the accountancy learning materials; (3) identify the students respons of the accountancy learning materials; (4) identify the competence improvement in the Manual Accountancy Practice Subject of XI Accountancy students in SMK Negeri 7 Yogyakarta after using accountancy learning materials. The method used in this research were research and development with four-D (4D) models. The data were collected by distributing questionnaire and conducting tests. The results of this research show that: (1)Development of accountancy learning materials was appropriate with the four-D model consisting of four primary steps which were, define, design, develop, and disseminate;(2) The feasibility of accountancy learning materials based on the assessment: the average score was 3.93 (feasible) from the material expert, 4.02 (feasible) from the media expert; and 4.03 (feasilbe) from an accountancy learning practitioner; (3) the students respons of the accountancy learning materials was 4.33 (very feasible); (4)Accountancy learning material was improve the competence in the Manual Accountancy Practice subject with the improvement of $59.36 \%$. The paired sample t-test analysis, it found that the avarage score was 4.70 from pre-test, and 7.49 from post-test showing that there was an increased score of $2.49, \quad t_{\text {count }}=-46.116$ and sig. $(p)=0.000$ showing that there was a significant difference between the pre-test and post-test score.
\end{abstract}




\section{PENDAHULUAN}

Pendidikan merupakan salah satu kegiatan universal dalam aktivitas manusia. Menurut Sugihartono, dkk (2012: 3) pendidikan adalah suatu usaha yang dilakukan secara sadar dan sengaja untuk mengubah tingkah laku manusia baik secara individu maupun kelompok untuk mendewasakan manusia melalui upaya pengajaran dan pelatihan. Pendapat tersebut menjelaskan bahwa tujuan dari pendidikan adalah untuk meningkatkan mutu Sumber Daya Manusia (SDM). Sebagaimana tercantum dalam Undang-Undang nomor 20 tahun 2013 pasal 3 yang menjelaskan bahwa pendidikan nasional berfungsi untuk mengembangkan kemampuan dan membentuk watak serta peradaban yang bermartabat dalam rangka mencerdaskan kehidupan bangsa, dan bertujuan untuk berkembangnya potensi peserta didik agar menjadi manusia yang beriman dan bertakwa kepada Tuhan Yang Maha Esa, berakhlak mulia, sehat, berilmu, cakap, kreatif, mandiri, dan menjadi warga negara yang demokratis serta bertanggung jawab.

Pemerintah Republik Indonesia menyusun standar nasional pendidikan yang berfungsi sebagai dasar dalam perencanaan, pelaksanaan, dan pengawasan pendidikan dalam rangka mewujudkan pendidikan nasional yang bermutu. Standar tersebut merupakan kriteria minimal tentang sistem pendidikan di seluruh wilayah hukum Negara Kesatuan Republik Indonesia yang diatur dalam Peraturan Pemerintah nomor 13 tahun 2015 tentang Standar Nasional Pendidikan.

Standar Nasional Pendidikan terdiri dari delapan standar, yang mana penetapan Standar Kompetensi Lulusan (SKL) digunakan sebagai acuan utama pengembangan standar-standar lainnya. Berdasarkan Peraturan Pemerintah nomor 13 tahun 2015 tentang Standar Nasional
Pendidikan menjelaskan bahwa Standar Kompetensi Lulusan merupakan kriteria mengenai kualifikasi kemampuan lulusan yang mencakup sikap, pengetahuan, dan keterampilan. SKL di Indonesia merujuk pada Bloom Taxonomy yang dikembangkan lebih lanjut oleh Anderson and Krathwol. Bloom Taxonomy mengkategorikan capaian pembelajaran menjadi tiga dimensi, yaitu dimensi pengetahuan, dimensi sikap, dan dimensi keterampilan. Setiap lulusan satuan pendidikan harus memiliki kompetensi pada tiga dimensi tersebut. Menurut E. Mulyasa (2006: 37-38) "Kompetensi merupakan perpaduan dari pengetahuan, keterampilan, nilai dan sikap yang direfleksikan dalam kebiasaan berpikir dan bertindak". Seseorang yang memiliki kompetensi tertentu bukan hanya mengetahui, tetapi juga dapat memahami dan menghayati bidang tersebut yang tercermin dalam pola perilaku sehari-hari.

Upaya pencapaian SKL dapat dilakukan dengan cara memaksimalkan proses pembelajaran dalam satuan pendidikan. Peraturan Pemerintah nomor 13 tahun 2015 tentang Standar Nasional Pendidikan pasal 19 ayat (1) menerangkan bahwa proses pembelajaran pada satuan pendidikan diselenggarakan secara interaktif, inspiratif, menyenangkan, menantang, memotivasi siswa untuk berpartisipasi aktif, serta memberikan ruang yang cukup bagi prakarsa, kreativitas, dan kemandirian. Proses pembelajaran sangat tergantung dengan komponen-komponen yang ada di dalamnya. Wina Sanjaya (2013: 58) menjelaskan bahwa komponen-komponen tersebut terdiri dari tujuan, materi pelajaran, metode atau strategi pembelajaran, media dan evaluasi.

Materi pelajaran atau lebih luas disebut sebagai bahan ajar merupakan salah satu komponen yang harus ada dalam proses pembelajaran. Bahan ajar merupakan segala 
bentuk bahan yang digunakan untuk membantu guru/instruktor dalam melaksanakan kegiatan belajar mengajar (Depdiknas, 2008: 6).

Sekolah Menengah Kejuruan (SMK) merupakan pendidikan menengah yang menyelenggarakan pendidikan kejuruan dalam mempersiapkan peserta didik untuk bekerja dalam bidang tertentu. Oleh sebab itu, SMK memiliki mata pelajaran produktif yaitu kelompok mata diklat yang berfungsi membekali siswa agar memiliki kompetensi kerja sesuai dengan Standar Kompetensi Kerja Nasional Indonesia (SKKNI).

Salah satu mata pelajaran produktif di jurusan akuntansi SMK Negeri 7 Yogyakarta adalah mata pelajaran Praktik Akuntansi Manual. Kompetensi yang harus dimiliki siswa setelah tuntas dalam mata pelajaran Praktik Akuntansi Manual adalah mampu mengerjakan

siklus akuntansi perusahaan jasa dan dagang. Sebagai mata pelajaran praktik, Praktik Akuntansi Manual memiliki karakteristik dalam proses pembelajaran yang berbeda dengan mata pelajaran lain. Mata pelajaran tersebut menuntut siswa untuk belajar mandiri. Martinis Yamin dan Maisah (2012: 140-141) menjelaskan belajar mandiri adalah cara belajar aktif dan partisipastif untuk mengembangkan diri masing-masing individu yang tidak terkait dengan kehadiran pembelajar, pertemuan tatap muka di kelas dan kehadiran teman sekolah. Implikasi utama kegiatan belajar mandiri adalah perlunya mengoptimalkan sumber belajar dengan tetap memberikan peluang otonomi yang lebih besar kepada siswa dalam mengendalikan kegiatan belajarnya.

Berdasarkan studi pendahuluan yang dilakukan peneliti, diperoleh informasi bahwa tingkat pencapaian kompetensi siswa dalam mata pelajaran Praktik Akuntansi Manual belum maksimal. Hal tersebut dapat dilihat dari hasil ulangan mata pelajaran produktif akuntansi kelas XI Akuntansi 3 di SMK Negeri 7 Yogyakarta. Dengan Kriteria
Ketuntasan Minimum (KKM) yang ditetapkan yaitu 70, hanya terdapat 6 siswa atau sebesar $19,35 \%$ dari 31 siswa yang mendapat predikat "Kompeten" dalam melaksanakan praktik akuntansi secara manual. Nilai rata-rata kelas yang diperoleh juga belum mencapai KKM, hanya sebesar 56,40 .

Mata pelajaran Praktik Akuntansi Manual merupakan salah satu mata pelajaran produktif yang tergolong sulit bagi siswa kelas XI pada Semester Gasal. Hal tersebut dikarenakan sebelumnya di kelas $\mathrm{X}$ siswa memperoleh materi siklus akuntansi secara terpisah sesuai Standar Kompetensi dan Kompetensi Dasar yang telah ditentukan. Kemudian, pada kelas XI siswa dituntut untuk mempraktikkan secara langsung dan menyeluruh dari materi-materi yang diperoleh selama kelas $\mathrm{X}$ dalam mata pelajaran Praktik Akuntansi Manual.

Selama proses pembelajaran praktik belum ada proses konstruksi dari konsep akuntansi yang dipraktikkan. Hal tersebut terlihat dari kebingungan yang dialami siswa ketika menemui soal praktik yang tidak sejenis dengan soal praktik yang telah dikerjakan sebelum-sebelumnya. Langkah terakhir yang dilakukan kebanyakan siswa ketika menemui kebingungan dalam mengerjakan soal praktik adalah meniru hasil pekerjaan salah satu teman yang telah selesai. Penggunaan bahan ajar yang tepat sangat berpengaruh terhadap pencapaian kompetensi siswa dalam menyelesaikan persoalan praktik akuntansi manual. Ika Lestari (2013: 2) menjelaskan bahwa bahan ajar adalah seperangkat materi pelajaran yang mengacu pada kurikulum yang digunakan untuk mencapai standar kompetensi dan kompetensi dasar yang telah ditentukan. Dengan adanya bahan ajar memungkinkan siswa untuk mempelajari suatu kompetensi atau kompetensi dasar secara runtut dan sistematis, sehingga secara akumulatif mampu menguasai semua kompetensi secara utuh dan terpadu. 
Pada kenyataannya, pembelajaran Praktik Akuntansi Manual di SMK Negeri 7 Yogyakarta tidak menggunakan bahan ajar maupun buku sumber selama proses pembelajaran berlangsung. Hal tersebut disebabkan karena tidak adanya bahan ajar yang menyajikan materi secara utuh sesuai dengan pembelajaran Praktik Akuntansi Manual di sekolah. Bahan ajar yang digunakan masih terbatas pada soal-soal praktik yang berasal dari Lomba Keterampilan Siswa (LKS) dan Ujian Kompetensi Kejuruan (UKK) dari tahun ke tahun. Selama proses pembelajaran siswa melakukan praktik penyelesaian siklus akuntansi untuk perusahaan jasa dan dagang secara manual dengan bantuan soal-soal praktik yang dimiliki sekolah dan lembar kerja untuk menyelesaikan soal tersebut. Praktik tersebut dilakukan secara bertahap dari mengelola buku jurnal hingga menyelesaikan siklus akuntansi berupa penyajian laporan keuangan.

Tidak adanya bahan ajar yang menyajikan materi sesuai dengan pembelajaran Praktik Akuntansi Manual di sekolah dalam satu buku paket menyebabkan siswa harus membuka kembali materi-materi yang ada pada buku paket saat kelas $\mathrm{X}$. Hal tersebut tentu menyulitkan siswa, karena disamping akan membuang waktu, siswa juga harus membawa berbagai macam buku paket yang berisikan materi Praktik Akuntansi Manual.

Di sisi lain, mata pelajaran Praktik Akuntansi Manual merupakan mata pelajaran penting bagi siswa Paket Keahlian Akuntansi. Hal tersebut dikarenakan, mata pelajaran Praktik Akuntansi Manual merupakan mata pelajaran yang dapat menunjang dan membantu siswa dalam melaksanakan Ujian Kompetensi Kejuruan (UKK) Paket Keahlian Akuntansi di kelas XII. Dengan kata lain, siswa harus memiliki pemahaman yang mendalam terhadap materi-materi dalam mata pelajaran Praktik Akuntansi Manual serta harus mencapai standar proses dan hasil yang telah ditentukan oleh sekolah.

Maka dari itu, perlu dilakukan upaya untuk meningkatkan kompetensi siswa dalam mata pelajaran Praktik Akuntansi Manual. Penggunaan bahan ajar yang tepat sesuai dengan karakteristik proses pembelajaran dapat menjadi alternatif bahan ajar yang dimanfaatkan untuk mendukung kelancaran proses belajar mengajar. Bahan ajar yang tepat untuk digunakan dalam proses pembelajaran Praktik Akuntansi Manual sesuai dengan karakteristik tersebut adalah modul.

Modul merupakan salah satu jenis bahan ajar cetak. Andi Prastowo (2015: 106) menjelaskan bahwa modul merupakan bahan ajar yang disusun secara sistematis dengan bahasa yang mudah dipahami oleh siswa, sesuai usia dan tingkat pengetahuan mereka agar siswa dapat belajar secara mandiri dengan bimbingan minimal dari pendidik. Pembelajaran menggunakan modul menurut Departemen Pendidikan Nasional (2008:7-8) dapat bermanfaat untuk (1) Meningkatkan efektivitas pembelajaran tanpa harus melalui tatap muka, (2) Menetapkan waktu belajar yang sesuai dengan kebutuhan dan perkembangan belajar siswa, (3) Secara tegas mengetahui pencapaian kompetensi siswa melalui kriteria yang telah ditetapkan dalam modul, dan (4) Mengetahui kompetensi yang belum dicapai siswa berdasarkan kriteria yang ditetapkan dalam modul sehingga guru dapat membantu untuk memperbaiki belajarnya.

Dengan demikian, peneliti bermaksud untuk meningkatkan kompetensi siswa pada mata pelajaran Praktik Akuntansi Manual dengan mengembangkan bahan ajar akuntansi berbentuk modul. Bahan ajar akuntansi tersebut diharapkan dapat membantu proses pembelajaran baik siswa maupun guru untuk meningkatkan kompetensi siswa serta membantu belajar mandiri siswa. Peneliti bermaksud untuk melakukan penelitian dengan judul 
"Pengembangan Bahan Ajar Berbentuk Modul Untuk Meningkatkan Kompetensi Siswa pada Mata Pelajaran Praktik Akuntansi Manual Kelas XI Akuntansi di SMK Negeri 7 Yogyakarta".

\section{METODE PENELITIAN}

\section{Jenis Penelitian}

Penelitian ini menggunakan penelitian dan pengembangan (research and development) yang mengacu pada model penelitian Thiagarajan, et al. (1974) yaitu four-D (4D) models.

\section{Waktu dan Tempat Penelitian}

Penelitian ini dilakukan di SMK Negeri 7 Yogyakarta yang beralamat di jalan Gowongan Kidul JT III/416 Yogyakarta 55232 pada tahun ajaran 2016/2017 Semester Gasal dari bulan Juni - September 2016.

\section{Target/Subjek Penelitian}

Subjek dalam penelitian ini terdiri dari 30 siswa kelas XI Akuntansi 3 SMK Negeri 7 Yogyakarta. Sementara itu, objek dalam penelitian ini adalah kelayakan bahan ajar akuntansi berbentuk modul dan peningkatan kompetensi siswa setelah menggunakan bahan ajar akuntansi berbentuk modul.

\section{Prosedur}

Prosedur penelitian dan pengembangan yang dilakukan mengacu pada model pengembangan 4D Models dengan empat tahapan pokok yaitu: (1) Define, (2) Design, (3) Develop, dan (4) Disseminate.Tahap define (pendefinisian) merupakan tahap untuk menetapkan dan mendefiniskan syarat-syarat yang dibutuhkan dalam pengembangan pembelajaran dengan melakukan analisis kebutuhan, analisis siswa, analisis kurikulum dan materi, serta spesifikasi tujuan. Tahap design (perancangan) merupakan tahap untuk merancang produk yang dikembangkan. Langkah-langkah dalam tahap ini terdiri dari penyusunan tes, pemilihan media, pemilihan format dan perancangan produk awal. Tahap develop (pengembangan) merupakan tahap yang bertujuan untuk menghasilkan bentuk akhir produk yang dikembangkan dengan melakukan validasi oleh ahli, revisi, dan uji coba pengembangan. Tahap disseminate (penyebaran) merupakan proses terakhir dalam penelitian dan pengembangan model Four-D dengan melakukan penyebaran produk hasil pengembangan di sekolah lain.

Data, Intrumen, dan Teknik

\section{Pengumpulan}

1) Data

Data dalam penelitian ini diambil dengan menggunakan angket dan tes. Angket digunakan untuk menilai kelayakan bahan ajar akuntansi berbentuk modul dari ahli materi, ahli media, dan praktisi pembelajaran akuntansi. Angket juga digunakan untuk mengetahui penilaian siswa terhadap bahan ajar akuntansi berbentuk modul. Angket yang digunakan dalam penelitian ini berupa angket tertutup dengan jenis rating scale. Tes digunakan untuk mengetahui peningkatan kompetensi siswa setelah menggunakan bahan ajar akuntansi berbentuk modul. Tes yang digunakan berupa tes praktik akuntansi dalam mengelola buku jurnal. Tes dilakukan dalam bentuk pre-test dan post-test dengan menggunakan penilaian kinerja.

2) Teknik Analisis Data

Pada penelitian ini menggunakan jenis data kualitatif dan data kuantitatif. Data kualitatif didapatkan dari masukan dan saran yang diberikan oleh ahli materi, ahli media dan praktisi pembelajaran akuntansi yang digunakan untuk perbaikan produk. Sedangkan data kuantitatif didapatkan dari penilaian ahli, dan respon siswa untuk mengetahui kelayakan Bahan Ajar Akuntansi Berbentuk Modul, serta tes praktik untuk mengetahui peningkatan 
Kompetensi Siswa Pada Mata Pelajaran Praktik Akuntansi Manual.

Analisis kelayakan Bahan Ajar Akuntansi Berbentuk Modul didapat dari angket validasi oleh ahli materi, ahli media, dan praktisi pembelajaran akuntansi. Data yang diperoleh kemudian dilakukan tabulasi data untuk setiap aspek penilaian dan butir penilaian dari masing-masing penilai. Dari data yang diperoleh kemudian dihitung skor rerata total dari setiap aspek penilaian dengan menggunakan rumus:

$$
\bar{x}=\frac{\sum x}{N}
$$

Keterangan:

$\overline{\boldsymbol{x}}:$ Skor rerata total

$\sum x$ : Jumlah rerata skor

$\mathrm{N}$ : Jumlah penilai

Selanjutnya rata-rata skor setiap aspek penilaian dideskripsikan dengan cara mengubah data kuantitatif menjadi data kualitatif berdasarkan kriteria penilaian Sukardjo (2012:98) dengan 5 skala penilaian. Kriteria penilaian tersebut ditampilan dalam Tabel 1.

\section{Tabel 1. Kriteria Penilaian}

\begin{tabular}{|l|l|}
\hline \multicolumn{1}{|c|}{ Interval Skor } & \multicolumn{1}{c|}{ Kriteria } \\
\hline $\bar{x} \geq \mathrm{Mi}+1,8 \mathrm{Sbi}$ & Sangat Layak \\
\hline $\mathrm{Mi}+0,6 \mathrm{Sbi}<\bar{x} \leq \mathrm{Mi}+1,8 \mathrm{Sbi}$ & Layak \\
\hline $\mathrm{Mi}-0,6 \mathrm{Sbi}<\bar{x} \leq \mathrm{Mi}+0,6 \mathrm{Sbi}$ & Cukup \\
\hline $\mathrm{Mi}-1,8 \mathrm{Sbi}<\bar{x} \leq \mathrm{Mi}-0,6 \mathrm{Sbi}$ & Tidak Layak \\
\hline $\bar{x} \leq \mathrm{Mi}-1,8 \mathrm{Sbi}$ & $\begin{array}{l}\text { Sangat Tidak } \\
\text { Layak }\end{array}$ \\
\hline
\end{tabular}

Keterangan:

$\mathrm{Mi}=1 / 2 \times$ (skor maks. ideal+skor min. ideal)

Sbi $=1 / 6 \mathrm{x}$ (skor maks. ideal-skor mi. ideal)

Analisis penilaian siswa terhadap Bahan Ajar Akuntansi Berbentuk Modul didapat dari angket penilaian siswa. Data yang diperoleh berupa data kualitatif, kemudian diubah menjadi data kuantatif sesuai skala penilaian dalam Tabel 2.

Tabel 2.Skala Penilaian

\begin{tabular}{|l|c|c|}
\hline Keterangan & $\begin{array}{l}\text { Skor } \\
\text { (positif) }\end{array}$ & $\begin{array}{l}\text { Skor } \\
\text { (negatif) }\end{array}$ \\
\hline SS (Sangat Setuju) & 5 & 1 \\
\hline S (Setuju) & 4 & 2 \\
\hline C (Cukup) & 3 & 3 \\
\hline TS (Tidak Setuju) & 2 & 4 \\
\hline STS (Sangat Tidak Setuju) & 1 & 5 \\
\hline
\end{tabular}

Dari data yang diperoleh kemudian dilakukan tabulasi data untuk setiap aspek penilaian dan butir penilaian dari masing-masing siswa. Data yang diperoleh kemudian dihitung rerata skor total penilaian dari setiap aspek penilaian. Rerata skor total kemudian dideskripsikan menjadi nilai kualitatif berdasarkan kriteria penilaian sesuai dengan Tabel 4 di bawah ini.

Tabel 3. Kriteria Penilaian untuk Siswa

\begin{tabular}{|l|l|}
\hline \multicolumn{1}{|c|}{ Interval Skor } & \multicolumn{1}{c|}{ Kriteria } \\
\hline $\bar{x} \geq \mathrm{Mi}+1,8 \mathrm{Sbi}$ & Sangat Baik \\
\hline $\mathrm{Mi}+0,6 \mathrm{Sbi}<\bar{x} \leq \mathrm{Mi}+1,8 \mathrm{Sbi}$ & Baik \\
\hline $\mathrm{Mi}-0,6 \mathrm{Sbi}<\bar{x} \leq \mathrm{Mi}+0,6 \mathrm{Sbi}$ & Cukup \\
\hline $\mathrm{Mi}-1,8 \mathrm{Sbi}<\bar{x} \leq \mathrm{Mi}-0,6 \mathrm{Sbi}$ & Tidak Baik \\
\hline $\bar{x} \leq \mathrm{Mi}-1,8 \mathrm{Sbi}$ & Sangat Tidak Baik \\
\hline
\end{tabular}

Keterangan:

Mi $=1 / 2$ x(skor maks. ideal+skor min. ideal)

Sbi $=1 / 6 \times($ skor maks. ideal-skor mi. ideal)

Analisis peningkatan kompetensi siswa diperoleh dari hasil nilai pre-test dan post-test yang didapatkan dari penilaian kinerja. Data yang diperoleh dihitung sesuai dengan pedoman penilaian kinerja yang telah ditentukan. Siswa dikatakan "Kompeten" apabila nilai akhir praktik $\geq 6,9$ sesuai dengan KKM pada mata pelajaran Praktik 
Akuntansi Manual di SMK N 7 Yogyakarta. Peningkatan Kompetensi Siswa Pada Mata Pelajaran Praktik Akuntansi Manual diketahui dari meningkatnya rata-rata nilai pre-test dan post-test siswa. Selain itu, juga dilakukan analisis paired sample t-test untuk mengetahui perbedaan signifikan antara nilai pre-test dan post-test. Kompetensi Siswa Pada Mata Pelajaran Praktik Akuntansi Manual dikatakan meningkat apabila nilai post-test lebih besar daripada nilai pre-test dan berdasarkan analisis paired sample $t$ test diperoleh nilai $t_{\text {hitung }}>t_{\text {tabel }}$ dengan signifikansi $<0,005$.

\section{HASIL PENELITIAN DAN PEMBA- HASAN}

Pengembangan Bahan Ajar Akuntansi Berbentuk Modul dikembangkan menggunakan 4D Models. Bahan ajar akuntansi berbentuk modul yang dikembangkan telah melalui tahapan 4D yaitu Pendefinisian (Define), Perencanaan (Design), Pengembangan (Develop), dan Penyebaran (Disseminate).

\section{Define}

Pada tahap define peneliti melakukan analisis kebutuhan, analisis siswa, analisis kurikulum, analisis materi dan spesifikasi tujuan. Analisis ini digunakan untuk menentukan media yang akan dikembangkan. Hasil analisis diketahui bahwa tingkat pencapaian kompetensi siswa pada mata pelajaran Praktik Akuntansi Manual masih rendah, hanya terdapat 6 dari 31 siswa yang mendapat predikat "Kompeten" dalam melaksanakan praktik akuntansi secara manual. Berdasarkan analisis yang dilakukan, rendahnya tingkat pencapaian kompetensi siswa salah satunya dikarenakan tidak digunakannya bahan ajar selama proses pembelajaran. Selain itu, siswa memiliki keinginan mencoba dalam melakukan praktik akuntansi secara manual. Akan tetapi, proses pembelajaran masih menggunakan pendekatan teacher centered, sehingga siswa tidak dapat belajar secara mandiri dan harus menunggu instruksi lisan dari guru untuk mempelajari pokok bahasan selanjutnya. Oleh karena itu, siswa membutuhkan bahan ajar yang dapat meningkatkan pencapaian kompetensi siswa dalam mata pelajaran Praktik Akuntansi Manual serta membantu belajar mandiri siswa. Bahan ajar tersebut disusun secara sistematis dan mengacu pada Standar Kompetensi dan Komptensi Dasar yang harus dicapai pada mata pelajaran Praktik Akuntansi Manual di SMK Negeri 7 Yogyakarta.

\section{Design}

Pada tahap design, peneliti menyusun tes, memilih media yang tepat, dan memilih format yang akan digunakan dalam pengembangan media, serta menulis naskah modul. Penyusunan tes merupakan langkah awal yang memhubungkan antara tahap define dan tahap design. Tes dalam penelitian ini digunakan untuk mengukur peningkatan kompetensi siswa melalui penggunaan bahan ajar yang dikembangkan. Tes yang digunakan dalam penelitian ini merupakan tes praktikum akuntansi secara manual yang disusun berdasarkan kompetensi dasar, materi, dan tujuan pembelajaran dalam mengelola buku jurnal. Terdapat 15 bukti transaksi dengan 3 perintah praktik yang harus dilakukan siswa dalam praktik akuntansi melalui pretest dan posttest.

Media yang dipilih berdasarkan analisis yang dilakukan pada tahap define berupa bahan ajar cetak berbentuk modul. Pemilihan bahan ajar cetak dikarenakan pembelajaran pada Mata Pelajaran Praktik Akuntansi Manual dilakukan tanpa menggunakan teknologi, yakni siswa diberikan soal untuk dikerjakan dalam lembar kerja yang telah disediakan secara manual. Bahan ajar yang dipilih berupa modul dikarenakan modul memiliki karakteristik yang sama dengan kondisi 
siswa dan proses pembelajaran di kelas. Pada mata pelajaran praktik Akuntansi Manual, siswa membutuhkan bahan ajar yang membantunya untuk belajar mandiri. Menurut Andi Prastowo (2015) modul merupakan bahan ajar yang disusun secara sistematis dengan bahasa yang mudah dipahami oleh siswa, sesuai usia dan tingkat pengetahuan mereka agar siswa dapat belajar secara mandiri dengan bimbingan minimal dari pendidik.

Format yang digunakan dalam penyusunan modul mengacu pada Depdiknas (2008). Format modul yang dimaksudkan terdiri dari komponenkomponen yang harus ada dalam modul. Komponen utama dalam modul merupakan kegiatan belajar yang berisi uraian materi beserta contoh dan penyelesaian, rangkuman, tes formatif, dan tugas. Adapun komponen yang menunjang dalam modul diantaranya tinjauan umum modul untuk memberikan gambaran tentang modul dan bagaimana menggunakan modul dan peta konsep modul untuk memberikan gambaran mengenai isi materi dalam modul. Untuk memenuhi syarat sebagai modul, terdapat halaman sampul modul, kata pengantar, daftar isi. Pada bagian akhir modul terdapat daftar pustaka berupa acuan buku yang digunakan dalam penyusuan modul dan glosarium untuk memudahkan pembaca memahami istilah-istilah penting.

Berdasarkan komponen-komponen modul yang telah dipilih, kemudian dilakukan penulisan modul. Modul yang ditulis berjudul Modul Praktik Akuntansi, siklus akuntansi perusahaan dagang. Penulisan modul diawali dengan perumusan Garis Besar Isi Modul (GIBM) yang dijadikan sebagai acuan utama untuk menyusun materi dalam modul. Kemudian dilajutkan dengan mengembangkan materi modul, yang terdiri dari uraian materi, contoh dan penyelesaian, rangkuman, tes formatif, dan tugas. Selanjutnya untuk memenuhi kriteria modul yang baik, peneliti melengkapi syarat teknis modul yang berupa bagian awal, tinjauan umum modul, peta konsep, dan bagian akhir modul. Pada tahap akhir dilakukan desain tampilan dan layout modul kemudian dicetak sehingga modul siap untuk divalidasi oleh ahli.

\section{Develop}

Tahap pengembangan bertujuan untuk menghasilkan bentuk akhir modul. Tahap pengembangan terdiri dari beberapa tahapan yaitu validasi ahli, revisi, dan uji coba pengembangan.

Hasil penulisan naskah modul sebelum diujicobakan pada subjek penelitian harus divalidasi terlebih dahulu oleh ahli dan praktisi. Tujuan validasi adalah untuk mengetahui kelayakan produk yang telah dikembangkan. Validator dalam penelitian ini adalah dosen ahli materi, dosen ahli media dan guru akuntansi sebagai praktisi pembelajaran akuntansi. Validator menilai kelayakan produk serta memberikan masukan dan saran untuk perbaikan produk yang dikembangkan.

Bahan Ajar Akuntansi Berbentuk Modul yang dinilai oleh ahli materi menggunakan angket skala 5 dengan 31 butir pertanyaan yang dikelompokkan menjadi 3 aspek, yaitu aspek kelayakan isi, aspek kebahasaan, dan aspek penyajian. Hasil penilaian kelayakan dari ahli materi ditunjukkan dalam Tabel 5.

Tabel 4. Hasil Penilaian Ahli Materi

\begin{tabular}{|l|c|l|}
\hline \multicolumn{1}{|c|}{ Aspek } & Rerata Skor & Kategori \\
\hline Kelayakan Isi & 4,00 & Layak \\
\hline Kebahasaan & 3,91 & Layak \\
\hline Penyajian & 3,89 & Layak \\
\hline Rerata Skor Total & $\mathbf{3 , 9 3}$ & Layak \\
\hline
\end{tabular}

Berdasarkan Tabel 4 tentang hasil penilaian oleh ahli materi, maka Bahan Ajar Akuntansi Berbentuk Modul dikategorikan "Layak", artinya Bahan Ajar Akuntansi Berbentuk Modul dari segi materi memiliki kelayakan isi yang baik, dengan bahasa yang mudah dipahami dan penyajian yang memudahkan pembaca.

Bahan Ajar Akuntansi Berbentuk Modul yang dinilai oleh ahli media menggunakan 
angket dengan 36 butir pertanyaan yang dikelompokkan menjadi 6 aspek, yaitu aspek konsistensi, aspek bentuk dan ukuran huruf, aspek format, aspek pengorganisasian, aspek daya tarik dan aspek ruang (spasi kosong). Hasil penilaian kelayakan dari ahli media ditunjukkan dalam Tabel 5.

Tabel 5. Hasil Penilaian Ahli Media

\begin{tabular}{|l|c|c|}
\hline \multicolumn{1}{|c|}{ Aspek } & $\begin{array}{c}\text { Rerata } \\
\text { Skor }\end{array}$ & Kategori \\
\hline Konsistensi & 4,40 & Sangat Layak \\
\hline Bentuk\&ukuran huruf & 3,86 & Layak \\
\hline Format & 4,00 & Layak \\
\hline Pengorganisasian & 3,88 & Layak \\
\hline Daya tarik & 4,00 & Layak \\
\hline Ruang & 4,00 & Layak \\
\hline Rerata Skor Total & $\mathbf{4 , 0 2}$ & Layak \\
\hline
\end{tabular}

Berdasarkan Tabel 6 tentang hasil penilaian oleh ahli media, maka bahan ajar akuntansi berbentuk modul dikategorikan "Layak", artinya Bahan Ajar Akuntansi Berbentuk Modul dari segi media memiliki daya tarik, format serta konsistensi dalam layout modul yang baik dengan pemilihan bentuk dan ukuran huruf yang tepat, serta pengorganisasian yang memudahkan dan dilengkapi dengan ruang untuk menjawab soal.

Bahan Ajar Akuntansi Berbentuk Modul yang dinilai oleh praktisi pembelajaran akuntansi menggunakan angket skala 5 dengan 40 butir pertanyaan yang dikelompokkan menjadi 4 aspek, yaitu aspek kelayakan isi, kebahasaan, penyajian, dan kegrafikan. Hasil penilaian kelayakan dari praktisi pembalajaran akuntansi ditunjukkan dalam Tabel 6.
Tabel 6. Hasil Penilaian Praktisi Pembelajaran

\begin{tabular}{|l|c|c|}
\hline \multicolumn{1}{|c|}{ Aspek } & $\begin{array}{c}\text { Rerata } \\
\text { Skor }\end{array}$ & Kategori \\
\hline Kelayakan Isi & 3,91 & Layak \\
\hline Kebahasaan & 4,00 & Layak \\
\hline Penyajian & 3,89 & Layak \\
\hline Kegrafikan & 4,33 & $\begin{array}{c}\text { Sangat } \\
\text { Layak }\end{array}$ \\
\hline Rerata Skor Total & $\mathbf{4 , 0 3}$ & Layak \\
\hline
\end{tabular}

Berdasarkan Tabel 6 tentang hasil penilaian oleh praktisi pembelajaran akuntansi, maka bahan ajar akuntansi berbentuk modul dikategorikan "Layak", artinya Bahan Ajar Akuntansi Berbentuk Modul dari segi pembelajaran memiliki kelayakan isi yang baik, kebahasaan yang mudah dipahami dan penyajian yang memudahkan pembaca serta kegrafikan yang menarik.

Langkah kedua yang dilakukan peneliti pada tahap develop yakni revisi. Bahan ajar yang telah divalidasi kemudian direvisi dan diperbaiki sesuai dengan masukan masingmasing validator.

Uji coba pengembangan merupakan langkah terakhir pada tahap develop. Uji coba pengembangan dilakukan untuk mengetahui penilaian siswa terhadap Bahan Ajar Akuntansi Berbentuk Modul, serta untuk mengukur Peningkatan Kompetensi Siswa Pada Mata Pelajaran Praktik Akuntansi Manual sebelum dan sesudah menggunakan Bahan Ajar Akuntansi Berbentuk Modul.

Penilaian siswa terhadap Bahan Ajar Akuntansi Berbentuk Modul diperoleh dari angket dengan skala 5. Angket yang diberikan memuat 25 butir pernyataan yang terdiri dari 4 aspek penilaian, yaitu: aspek kelayakan isi, kebahasaan, penyajian, dan kegrafikan. Hasil penilaian siswa terhadap bahan ajar akuntansi berbentuk modul dapat dilihat pada Tabel 7. 
Tabel 7. Hasil Penilaian Siswa

\begin{tabular}{|l|c|c|}
\hline \multicolumn{1}{|c|}{ Aspek } & Rerata Skor & Kategori \\
\hline Kelayakan Isi & 4,44 & $\begin{array}{c}\text { Sangat } \\
\text { Baik }\end{array}$ \\
\hline Kebahasaan & 4,31 & $\begin{array}{c}\text { Sangat } \\
\text { Baik }\end{array}$ \\
\hline Penyajian & 4,36 & $\begin{array}{c}\text { Sangat } \\
\text { Baik }\end{array}$ \\
\hline Kegrafikan & 4,21 & $\begin{array}{c}\text { Sangat } \\
\text { Baik }\end{array}$ \\
\hline $\begin{array}{l}\text { Rerata Skor } \\
\text { Total }\end{array}$ & $\mathbf{4 , 3 3}$ & $\begin{array}{c}\text { Sangat } \\
\text { Baik }\end{array}$ \\
\hline
\end{tabular}

Berdasarkan Tabel 7 tentang hasil penilaian siswa terhadap bahan ajar akuntansi, maka bahan ajar akuntansi berbentuk modul dikategorikan "Sangat Baik", artinya Bahan Ajar Akuntansi Berbentuk Modul dari segi kelayakan materi, kebahasaan, penyajian dan kegrafikan sangat baik untuk diterapkan pada siswa kelas XI Akuntansi.

Penilaian kompetensi siswa diperoleh dari hasil pre-test dan post-test siswa dalam mata pelajaran Praktik Akuntansi Manual materi Mengelola Buku Jurnal menggunakan penilaian kinerja siswa dengan 5 komponen penilaian, yaitu: persiapan, proses kerja, hasil kerja, sikap kerja dan waktu kerja.

Komponen persiapan kerja menilai kemampuan siswa untuk mempersiapkan alat dan bahan dalam praktik akuntansi. Komponen proses kerja menilai kemampuan siswa dalam memproses bukti transaksi ke dalam jurnal. Komponen hasil kerja menilai kemampuan siswa dalam hasil penjurnalan. Sikap kerja menilai kerapian dan keterbacaan tulisan. Sedangkan komponen waktu kerja menilai kecepatan dan keefektifan waktu siswa dalam melakukan praktik.

Hasil penilaian kompetensi siswa diperoleh rerata nilai pre-test siswa sebesar 4,70 dengan kategori "Tidak kompeten" dan rerata nilai post-test siswa sebesar 7,49 dengan kategori "Kompeten". Analisis paired sample t-test dilakukan untuk mengetahui perbedaan antara nilai pre-test dan post-test. Hasil analisis paired sample ttest diperoleh nilai $\mathrm{t}_{\text {hitung }}=-46,116$ dan sig.(p) $=0,000$ yang menunjukkan adanya perbedaan antara nilai pre-test dengan nilai post-test. Dengan demikian, Bahan Ajar Akuntansi Berbentuk Modul dapat meningkatkan Kompetensi Siswa Pada Mata Pelajaran Praktik Akuntansi Manual. Perbandingan nilai pre-test dan post-test siwa dapat dilihat pada Gambar 1.

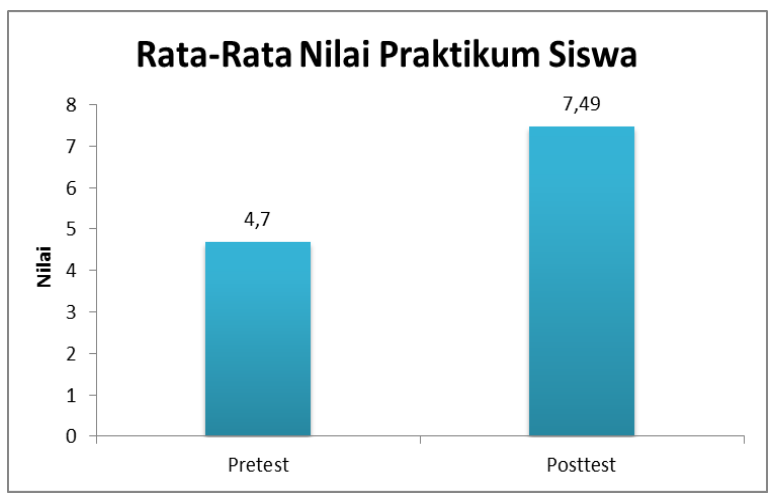

Gambar 1. Perbandingan nilai pretest dan posttest siswa

Peningkatan kompetensi siswa juga dapat dilihat dari kenaikan nilai pada masing-masing komponen dalam pre-test dan post-test. Perbandingan rata-rata nilai pre-test dan post-test siswa pada masingmasing komponen penilaian ditampilan dalam Tabel 8 berikut ini.

Tabel 8. Perbandingan rerata nilai pretest dan post-test siswa

\begin{tabular}{|l|c|c|c|}
\hline $\begin{array}{c}\text { Kompo- } \\
\text { nen }\end{array}$ & $\begin{array}{c}\text { Nilai } \\
\text { Pre-test }\end{array}$ & $\begin{array}{c}\text { Nilai } \\
\text { Post-test }\end{array}$ & $\begin{array}{c}\text { Kenaikan } \\
(\%)\end{array}$ \\
\hline $\begin{array}{l}\text { Persiapan } \\
\text { kerja }\end{array}$ & 7,60 & 7,78 & 2,41 \\
\hline $\begin{array}{l}\text { Proses } \\
\text { kerja }\end{array}$ & 4,06 & 7,76 & 90,96 \\
\hline Hasil kerja & 3,59 & 7,29 & 102,91 \\
\hline Sikap kerja & 7,53 & 7,62 & 1,11 \\
\hline $\begin{array}{l}\text { Waktu } \\
\text { kerja }\end{array}$ & 7,55 & 7,58 & 0,44 \\
\hline
\end{tabular}

Berdasarkan Tabel 8 mengenai perbandingan rerata nilai pre-test dan posttest siswa, diperoleh informasi bahwa 
masing-masing komponen penilaian mengalami peningkatan dalam post-test dengan peningkatan tertinggi pada hasil kerja dan peningkatan terendah pada waktu kerja.

\section{Disseminate}

Penyebaran Bahan Ajar Akuntansi Berbentuk Modul dilakukan di sekolah lain yang memiliki karakteristik yang sama. Sekolah yang dipilih yakni SMK yang memiliki jurusan akuntansi di kota Yogyakarta, yang terdiri dari 3 SMK yakni SMK Negeri 1 Yogyakarta, SMK Koperasi, dan SMK Muhammadiyah 2 Yogyakarta. Penyebaran produk dilakukan dengan memberikan modul yang telah dikembangkan disertai dengan lembar kerja dan kunci jawab kepada guru produktif akuntansi untuk dapat digunakan sebagai alternatif bahan ajar di sekolah tersebut.

\section{Kajian Produk Akhir}

Produk akhir pada penelitian ini adalah Modul Praktik Akuntansi siklus akuntansi perusahaan dagang yang berbentuk media cetak. Modul tersebut digunakan untuk mata pelajaran Praktik Akuntansi Manual kelas XI Akuntansi yang terdiri dari 3 kegiatan belajar, yaitu:

Kegiatan Belajar 1 Mengelola Buku Jurnal Kegiatan Belajar 2 Mengelola Buku Besar Kegiatan Belajar 3 Menyelesaikan Siklus

\section{Akuntansi}

Komponen-komponen yang terdapat dalam modul terdiri dari: sampul modul, kata pengantar, daftar isi, daftar tabel dan daftar gambar, peta konsep modul, tinjauan umum modul, kegiatan belajar, evaluasi, daftar pustaka, dan glosarium. Kegiatan belajar merupakan komponen utama dalam modul yang disusun, kegiatan belajar memuat uraian materi, contoh dan penyelesaian, rangkuman, tugas dan tes formatif beserta kunci jawaban.

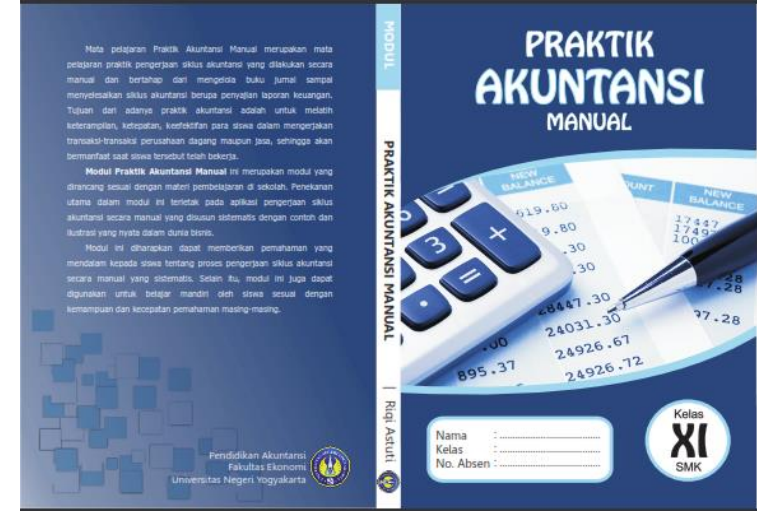

\section{Gambar 1. Tampilan Modul Praktik} Akuntansi

\section{SIMPULAN DAN SARAN \\ Simpulan}

Berdasarkan hasil penelitian dan pengembangan dan pembahasan, dapat disimpulkan beberapa hal sebagai berikut: (1) Pengembangan Bahan Ajar Akuntansi Berbentuk Modul pada mata pelajaran Praktik Akuntansi Manual dikembangkan menggunakan model Four-D. Define, diperoleh hasil bahwa siswa membutuhkan bahan ajar yang dapat meningkatkan kompetensi siswa, serta membantu belajar mandiri. Design, diperoleh hasil bahan ajar yang sesuai kebutuhan siswa berupa modul praktik akuntansi. Develop, dilakukan validasi oleh ahli, revisi sesuai saran ahli, serta uji coba pengembangan di kelas XI Akuntansi 3. Disseminate, dilakukan penyebaran modul di SMK Muhammadiyah 2 Yogyakarta, SMK Negeri 1 Yogyakarta, dan SMK Koperasi. (2) Kelayakan Bahan Ajar Akuntansi Berbentuk Modul berdasarkan penilaian oleh ahli materi memperoleh skor rata-rata seluruh aspek sebesar 3,93 (Layak), ahli media 4,02 (Layak), dan praktisi pembelajaran akuntansi 4,03 (Layak); (3) Penilaian siswa terhadap Bahan Ajar Akuntansi Berbentuk Modul memperoleh skor rata-rata seluruh aspek sebesar 4,33 (Sangat Baik); (4) Bahan Ajar Akuntansi Berbentuk Modul dapat meningkatkan Kompetensi Siswa Pada Mata Pelajaran Praktik Akuntansi Manual. Dari hasil perhitungan yang dilakukan dengan 
membadingkan nilai pre-test dan post-test serta menguji nilai tersebut dengan paired sample t-test, Bahan Ajar Akuntansi Berbentuk Modul dapat meningkatkan Kompetensi Siswa Pada Mata Pelajaran Praktik Akuntansi Manual sebesar 2,49 $(59,36 \%)$ dari nilai pretest sebesar 4,70 meningkat menjadi 7,49 saat posttest dengan nilai $t_{\text {hitung }}=-46,116$ dan sig. $(\mathrm{p})=0,000$.

\section{Saran}

Berdasarkan hasil dan pembahasan penelitian pengembangan, Bahan Ajar Akuntansi Berbentuk Modul masih memiliki kekurangan yang perlu diperbaiki. Oleh sebab itu, peneliti memberikan saran berikut untuk penelitian lanjutan: (1) Pengembangan modul praktik akuntansi manual perlu dilakukan untuk standar kompetensi mengerjakan siklus akuntansi perusahaan dagang dengan sistem pencatatan periodik; (2) Perlu dilakukan penelitian eksperimen untuk menguji efektivitas modul menggunakan kelas eksperimen dan kelas kontrol; dan (3) Modul praktik akuntansi manual yang telah dikembangkan diharapkan dapat digunakan di sekolah-sekolah yang memiliki karakteristik sama dengan karakteristik sekolah uji coba.

\section{DAFTAR PUSTAKA}

Andi Prastowo. (2015). Panduan Kreatif Membuat Bahan Ajar Inovatif. Yogyakarta: DIVA Press.

Departemen Pendidikan Nasional (2008). Panduan Pengembangan Bahan Ajar. Jakarta: Depdiknas.

E.Mulyasa. (2003). Kurikulum Berbasis Kompetensi Konsep, Karakteristik dan Implementasi. Bandung: Remaja Rosdakarya.

Ika Lestari. (2013). Pengembangan Bahan Ajar Berbasis Kompetensi Sesuai dengan Kurikulum Tingkat Satuan Pendidikan. Padang: Akademika Permata.
Martinis Yamin dan Maisah. (2012). Manajemen Pembelajaran Kelas: Strategi Meningkatkan Mutu Pembelajaran. Jakarta: Gaung Persada Press.

Peraturan Pemerintah nomor 13 tahun 2015 tentang Standar Nasional.

Pendidikan Sugihartono, dkk. (2012). Psikologi Pendidikan. Yogyakarta: UNY Press.

Sukardjo. (2012). Evaluasi Program Pembelajaran. Yogyakarta: Pps UNY

Wina Sanjaya. (2013). Strategi Pembelajaran Berorientasi Standar Proses Pendidikan. Jakarta: Kencana Prenada Media Group. 